May 17th, 9:30 AM

\title{
Seasonal Variation of Nutrient Loading in a Stoichiometric Producer-Consumer System
}

Lale Asik

Texas Tech University, lale.asik@ttu.edu

Jackson kulik

Texas Tech University, jackson.kulik@ttu.edu

Kevin R. Long

Texas Tech University, kevin.long@ttu.edu

See next page for additional authors

Follow this and additional works at: https://scholarscompass.vcu.edu/bamm

Part of the Ordinary Differential Equations and Applied Dynamics Commons

https://scholarscompass.vcu.edu/bamm/2019/fri/2

This Event is brought to you for free and open access by the Dept. of Mathematics and Applied Mathematics at VCU Scholars Compass. It has been accepted for inclusion in Biology and Medicine Through Mathematics Conference by an authorized administrator of VCU Scholars Compass. For more information, please contact libcompass@vcu.edu. 
Presenter Information

Lale Asik, Jackson kulik, Kevin R. Long, and Angela Peace 


\title{
Seasonal Variation of Nutrient Loading in a Stoichiometric Producer-Consumer System
}

\author{
Lale Asik ${ }^{1, *}$, Jackson Kulik ${ }^{1}$, Kevin R. Long ${ }^{1}$, and Angela Peace ${ }^{1}$ \\ ${ }^{1}$ Department of Mathematics and Statistics, Texas Tech University, Lubbock, USA \\ lale.asik@tttu.edu
}

Recent discoveries in ecological stoichiometry have indicated that food quality in terms of the phosphorus:carbon $(\mathrm{P}: \mathrm{C})$ ratio affects consumers whether the imbalance involves insufficient or excess nutrients. This phenomenon is called the "stoichiometric P:C knife-edge." In this study, we develop and analyze a producer-consumer model which captures this phenomenon. It assesses the effects of (external) nutrient (P) loading on consumer dynamics in an aquatic environment by mechanistically deriving and accounting for seasonal variation in nutrient loading. In the absence of seasonal effects, previous models suggest that the dynamics are Hopf bifurcation, saddle-node bifurcations, and limit cycles. However, seasonal effects can have major implications on the predicted solutions and enrich population dynamics. Bifurcation analysis demonstrates that seasonal forcing can cause both periodic and quasi-periodic solutions. 